\title{
An Introduction to the Central Credit Register
}

\author{
Benjamin Doyle \\ Training Officer
}

(C) Author(s). This work is licensed under the Creative Commons Attribution-NonCommercialShareAlike 4.0 International License. To view a copy of this license, visit https://creativecommons.org/licenses/by-nc-sa/4.0/ .

\section{Glossary of terms}

Consumer: "A natural person, acting outside their trade, business or profession" (Central Bank of Ireland, 2017b).

Non-Consumer: "A sole trader or company who purchases goods and services for business use" (First Citizen, 2018).

Lender: "Credit Information Provider - any person who provides credit including a regulated financial services provider; NAMA; a local authority; and any other person who provides credit. The Central Bank of Ireland, any other Central Bank, and pawnbrokers are excluded" (Central Bank of Ireland, 2017b).

Credit: "A loan, deferred payment or other form of financial accommodation other than that provided by one credit institution to another; to any entity classified within general government; inter-company lending; where credit is provided only to employees; for provision of utilities; purchase of goods or services from the person by whom the credit is provide or where no interest or any other charge is payable" (Central Bank of Ireland, 2017b).

Credit Report: "Hardcopy or softcopy document that is produced by the Central Credit Register in response to a request for access" (Central Bank of Ireland, 2017b).

PPSN: Personal public service number.

TRN: Tax Reference Number

Facility: A mortgage, overdraft, credit card, personal loan or business loan.

\section{Introduction}

The Central Credit Register (CCR) was established following the Credit Reporting Act of 2013. This Act was established subsequent to the European Union and the International Monetary Fund Programme providing financial support to Ireland in 2010 after the banking crisis of 2008. Three agents played a central role in the 2008 banking crisis; The Central Bank, lenders and the Government. Lenders failed in their direction 
and management of banking practices, the Government relied too greatly on the construction sector and other temporary sources for revenue. Finally, the Central Bank, lacked a sufficient regulatory approach, bank supervision and action (Honohan, Donovan, Gorecki \& Mottiar, 2010).

One of the obligations for providing financial support to Ireland was the creation of the CCR by the Central Bank of Ireland. The Central Bank will use information, collected by lenders on borrowers, from the CCR to ensure future financial stability in Ireland by the following means: Identifying and implementing actions to help reduce or remove financial and economic risks to Ireland as well as using collected data to help lenders identify creditworthiness, thus helping the Central Bank to supervise Ireland's financial sector (Credit Reporting Act, 2013; Central Bank of Ireland, 2017f).

Since the 30th of June 2017 , consumers who apply for a facility or have a facility still open as of this date, of 500 Euro or more will be reported to the CCR by the lender who received their facility application. The credit facilities included for the consumer are: mortgages, overdrafts, credit cards and personal loans. Since the 30th of March 2018, all non-consumers who have an open facility for 500 Euro or more will report to the CCR. Credit facilities included for non-consumers are any business loans over 500 Euro (Central Bank of Ireland, 2017f).

Under the Credit Reporting Act of 2013, the CCR collects both personal and financial information from lenders on borrowers. The personal information collected includes (Central Bank of Ireland, 2017e):

- Name

- Gender

- PPSN/TRN

- Date of birth

- The borrowers current and previous addresses (if any)

- The borrowers telephone number.

The financial information collected includes:

- The type of loan

- Name of the lender who provided the loan

- The amount of the loan

- The outstanding balance on the loan

- The number of payments past due

- The date of when the next payment is to be made

- The amount the next payment is for

\section{Consumer Reporting}

Since the 30th of June 2017, all lenders who provide credit facilities of 500 Euro or more are legally required to submit the aforementioned personal and credit information 
regarding consumers. This submitted information will only apply to consumers who currently have a credit facility of 500 Euro or more or are granted a credit facility for this amount or more since June 2017. This information will be reported to the CCR each month by the lenders until the credit facility is completed. Once the facility is closed, it will no longer be reported to the CCR. However, the previously reported months will remain viewable to the consumer for five years and to the lender for two years (Central Bank of Ireland, 2017e).

\section{Non-Consumer Reporting}

Since the 30th of March 2018, all lenders who provide credit facilities, for the previously specified amount, will be legally required to submit business customer information and financial information regarding non-consumers. This information will be reported monthly to the CCR until the credit facility is completed. As mentioned above for the consumers, once the facility is completed the reporting ceases and the previously reported months remain viewable to the non-consumer for five years and to the lender for two years. (Central Bank of Ireland, 2017e).

\section{Credit Reports}

Credit reports have been available since March 2018 and can be accessed by going to the CCR website and applying for a report. A credit report for a consumer will contain all their credit applications of 500 Euro or more that have been opened or are still open since June 2017. Credit reports can only be generated by the data contained on the CCR. This information includes all credit facilities of 500 Euro or more from all the lenders that the consumer has received. The information is reported monthly and is stored for five years - anything older will be deleted. Credit reports will also contain the most recent six months history of credit applications that the consumer has applied for, regardless of whether they have been granted or not (Central Bank of Ireland, 2017a).

The credit information that is reported can reflect positively or negatively on a consumer. Positive credit information would show a consumer has not missed a payment on their credit facilities, whereas negative credit information would show each payment a consumer has missed on their facilities. The amount of arrears is not shown on the credit report. When viewing this report lenders may use information on any payments past due as an indicator that the consumer will not be able to fulfil their repayments and can potentially result in the denial of the facility. Consumers have the option to add a note of 200 words or less to each monthly report on each credit facility that they have. This may be used to explain why a payment was missed (Central Bank of Ireland, 2017h).

Consumers can view the previous five years of their lending history. Lenders will only be able to access the most recent two years of a consumers lending history and should a lender access a consumer's credit report, a digital footprint at the bottom of the report 
will be created detailing the lenders name, the time and date the report was accessed and for what reason. Lenders can only request a credit report when:

- A consumer has made an application for a new facility.

- The consumer wishes to have a facility restructured

- If a consumer has arrears on one of their facilities

- If the consumer has exceeded their limit on their credit card or overdraft.

Since September 30th, 2018, lenders must request a copy of a consumer's credit report when that consumer applies for a credit facility over 2000 Euro (Central Bank of Ireland, 2017f).

Consumers have the right to request that their credit report be amended if they believe that their report contains incorrect information. They can do so by contacting the lender that they believe is providing the inaccurate information or by contacting the CCR directly.

It is important to be aware that the CCR will not issue grades on credit reports. It is up to lenders to interpret consumer data and decide if the consumer meets the criteria for the credit application for which they are applying. One should also note that even if a consumer has positive credit information on their report, such as not missing payments on their facilities, this does not guarantee an automatic approval for subsequent credit facilities (Central Bank of Ireland, 2017e).

\section{PPSN/TRN Capture}

Since the 30th of September 2018, lenders must capture the PPSN/TRN of consumers applying for a credit application of 500 Euro or more. This makes it easier to match consumer data over multiple credit facilities. Equally, since the 30th of September 2018, no consumer will be able to apply/receive a credit application of 500 Euro or more without letting the lender capture their PPSN/TRN (EBS, 2018).

\section{The Central Credit Register and the Irish Credit Bureau:}

The Irish Credit Bureau (ICB) is a database containing information regarding the performance of credit agreements between borrowers and financial institutions and has been in place since 1963. The biggest difference between the CCR and the ICB is that the CCR is mandatory, whereas the ICB is voluntary. With the establishment of the CCR in June 2017, the future of the ICB may be impacted, as once sufficient data has built up in the CCR to provide an accurate credit history for consumers, the ICB may no longer be necessary. However, for now, both will continue to report in tandem; the CCR to the Central Bank of Ireland and the ICB to financial institutes. The ICB and CCR will still be used by lenders to determine if a consumer can be granted a credit facility (Hamilton, 2018) 


\section{GDPR}

Consumers or non-consumers have the right to:

- Access any information that the Central Bank of Ireland holds on them,

- See who has accessed their information,

- Have any information that is incorrect investigated/ rectified and forgotten once their credit facility has been closed after a period of 5 years.

The Data Controller for the Central Credit Register is the Central Bank of Ireland (Central Bank of Ireland, 2017a).

\section{Fines and Penalties}

Any lender submitting false information to the CCR or using the information gathered for reasons not stated in the Credit Reporting Act 2013 are committing an offence. Offenders can face fines and or imprisonment (Credit Reporting Act, 2013). Any lender committing offences against the data protection policies outlined by the GDPR, can face fines up to $4 \%$ of their previous financial year or $€ 20$ Million, whichever is highest (General Data Protection Regulation, 2016).

\section{Lender Compliance}

Lenders need to ensure they are compliant with the Credit Reporting Act of 2013. This can be done by achieving the following:

- From June 2017 they must submit personal information and financial information for consumers on credit facilities of 500 Euro or more for the following products; mortgages, overdrafts, personal loans and credit cards.

- From March 2018 they must submit business customer information and financial information for non-consumers on credit facilities of 500 Euro or more for the following products; business loans.

- Meet the PPSN/TRN capture for relevant consumers by September 30th, 2018.

- From the 30th of September 2018 onwards, they must request a copy of a consumer's credit report when a consumer applies for a credit facility over 2000 Euro.

- Carrying out amendments to incorrectly reported information on borrowers.

- Ensure all staff who deal with credit facilities or directly with consumers/ nonconsumers have been trained on the CCR. 


\section{Recommended Sources for further information}

\begin{tabular}{|l|l|}
\hline The Central Bank of Ireland's Website & https://www.centralbank.ie \\
\hline Website for Ireland's Central Credit Register & https://www.centralcreditregister.ie \\
\hline Website for the Irish Credit Bureau & http://www.icb.ie \\
\hline The Credit Reporting Act 2013 & http://www.irishstatutebook.ie/eli/2 \\
& 013/act/45/enacted/en/pdf \\
\hline
\end{tabular}

This article is general information and does not constitute legal advice or analysis.

\section{References}

Central Bank of Ireland (2017a) Data Protection. Available at:

https://www.centralcreditregister.ie/borrower-area/data-protection/ (Accessed: 14 October 2018).

Central Bank of Ireland (2017b) Glossary. Available at:

https://www.centralcreditregister.ie/about/glossary/ (Accessed: 14 October 2018).

Central Bank of Ireland (2017c) Publications. Available at:

https://www.centralcreditregister.ie/borrower-area/publications/ (Accessed: 10 August 2018)/

Central Bank of Ireland (2017d) What is included on the Central Credit Register?. Available at: https://www.centralcreditregister.ie/about/what-is-included/ (Accessed: 10 August 2018).

Central Bank of Ireland (2017e) What is included on the credit report?. Available at: https://www.centralcreditregister.ie/borrower-area/the-credit-report/ (Accessed: 10 August 2018).

Central Bank of Ireland (2017f) What is the Central Credit Register?. Available at: https://www.centralcreditregister.ie/about/background/ (Accessed: 20 August 2018)

Central Bank or Ireland $(2017 \mathrm{~g})$ Who can request a credit report?. Available at: https://www.centralcreditregister.ie/borrower-area/who-can-request-a-credit-report/ (Accessed: 10 August 2018).

Central Bank of Ireland (2017h) Your Rights. Available at:

https://www.centralcreditregister.ie/borrower-area/your-rights/ (Accessed: 10 August 2018).

Credit Reporting Act (2013) Number 45 of 2013. Irish Statute Book. Available at:

http://www.irishstatutebook.ie/eli/2013/act/45/enacted/en/pdf (Accessed 18 August 2018).

EBS (2018) Central Credit Register. Available at: https://www.ebs.ie/central-credit-register (Accessed: 24 August 2018). 
First Citizen. (2018). Non Consumers. Available at:

https://www.firstcitizen.ie/products/agri/non-consumers.php (Accessed October 14 2018).

General Data Protection Regulation (2016). Regulation (EU) 2016/679 of the European Parliament and of the Council of 27 April 2016 on the protection of natural persons with regard to the processing of personal data and on the free movement of such data, and repealing Directive 95/46. Official Journal of the European Union (OJ), 59 (1-88), 294 [Online]. Available at:

https://eur-lex.europa.eu/legal-content/EN/TXT/PDF/?uri=CELEX:32016R0679\&from=EN (Accessed 14 November 2018).

Hamilton, R. (2018) The Central Credit Register and your credit report: what you need to know [Online] Available at https://www.bonkers.ie/blog/personal-finance/the-central-creditregisterl (Accessed November 15, 2018).

Honohan, P., Donovan, D., Gorecki, P. and Mottiar, R. (2010) The Irish Banking Crisis: Regulatory and Financial Stability Policy [Online]. Available at: https://mpra.ub.unimuenchen.de/24896/1/The_Irish_Banking_Crisis_Regulatory_and_Financial_Stability_Polic y_2003-2008.pdf (Accessed August 24, 2018). 